\title{
Role of Cytokines as Biomarkers in Arthritic Rats and the Efficiency of Diclofenac \\ Therapy in the Presence of some Antioxidants
}

Heibashy, M. I.; El-Negamy, F. A..; Shahin, M. I. ; Hassanin, M. S. and Hammad, W. A."

Biological Applications Department, Nuclear Research Center, Atomic Energy Authority, Egypt.

"Zoology Department, Faculty of Women for Arts, Science and Education, Ain Shams University.

\begin{abstract}
Rheumatoid arthritis (RA) is an autoimmune disease accompanied by hyperplasia of the cartilage caused by infiltration of inflammatory cells and resulting in joint damage. Diclofenac is one of the most prospective and commercially successful drugs in the family of nonsteroidal anti-inflammatory drugs (NSAIDs) used for the treatment of rheumatoid arthritis. Curcumin, a member of the curcuminoid family of compounds has antioxidant and anticarcinogenic activities which have been attributed to its hydroxyl and methoxy groups. Quercetin is categorized as a flavonol has been shown to exert antimicrobial, antiviral, anti-inflammatory and antioxidant activities. Curcumin and quercetin are antioxidant molecules with antiproliferative, anti-inflammatory and immunosuppressive activities. The objective of this study was to investigate the inhibitory activity of these three agents on inflammatory aspects of arthritis. This experiment was carried out on adult male albino rats and included two experiment, the first one aimed to show the changes occurred in some physiological and biochemical parameters in serum and tissue as a result of arthritis induction which was induced by injection $150 \mu \mathrm{l}$ pristine. In the second experiment, five comparisons were made between normal control rats and another four animal groups suffering from arthritis. The $1^{\text {st }}$ group of them was injected intramuscularity with diclofenac $(5 \mathrm{mg} / 100 \mathrm{~g} \mathrm{~b} . w \mathrm{t})$ for 1,2 and 4 weeks. The $2^{\text {nd }}$ group was treated with diclofenac and administrated orally with $100 \mathrm{mg}$ curcumin $/ 100 \mathrm{~g}$ b.wt. for 1, 2 and 4 weeks. The $3^{\text {rd }}$ animal group was treated with diclofenac and administrated orally $100 \mathrm{mg}$ quercetin $/ 100 \mathrm{~g}$ b.wt. for the same pervious intervals. The $4^{\text {th }}$ arthritic animal group treated with diclofenac, curcumin and quercetin as described before for the same times. In this study, the obtained results revealed that induction of arthritis in rats caused a significant elevation in the levels of C-reactive protein (CRP), interleukin-1 $\alpha$ (rat IL-1 $\alpha$ ), interleukin-6 (IL-6) and tumor necrosis factor- $\alpha$ (TNF- $\alpha)$. Also, in arthriric rats, serum total antioxidant capacity (TAC) decreased while total oxidative capacity (TOC), total antioxidant, total nitric oxide (TNO) and resistin increased. In joint cartilage of arthritic rats, prostaglandin (PGE2), cyclooxygenase (COX-2), malondialdehyde (MDA) and resistin levels were remarkably increased compared to those normal control animals. All previous parameters were corrected after the administration of diclofenac with curcumin or/and quercetin depending on the time of treatment $(1,2 \& 4$ weeks). The data were discussed according to available obtained researches.
\end{abstract}

Key words: Arthritis, Cytokines, Diclofenac, Curcumin, Quercetin

wafaa.hammad@women.asu.edu.eg 


\section{Introduction}

Arthritis is a chronic proinflammatory disease that is characterized by hyperplasia of the synovial fibroblasts, which is partly the result of decreased apoptosis and joint stiffness and swelling, often manifesting in a symmetrical pattern on both sides of the body (Park et al., 2007). Arthritis is more prevalent in the Western world than in other countries, although, the precise reason for this predilection is not well understood, lifestyle is known to play a major role. Rheumatoid arthritis (RA) occurs in women more often than men. Smoking and stresses are thought to contribute to RA (Aggarwal \& Harikumar, 2009). Several researches do not know exactly why RA develops. They speculate that a combination of factors including genetic susceptibility, an abnormal immune response and certain changes in the body such as an infection or hormonal shift can trigger its development (Lee \& Weinblatt, 2001 and Yen et al., 2001).

A major strategy to control inflammation and alleviate pain is by reducing the levels of prostaglandins (PGs), the paracrinc and autocrinc mediators of inflammation (Smith et al., 2000). This makes the cyclooxygenase (COX1 and COX2) key enzymes in prostaglandin (PG) production and drug targets for arthritis treatment (Ge et al., 2006 and Chen et al., 2008). NSAIDs can reduce COX activity (Schumacher \& Chen, 2005 and Towheed, 2006).

Diclofenac is a nonsteroidal anti-inflammatory drug (NSAID) commonly used to reduce inflammation and pain associated with arthritis, osteoarthritis, rheumatoid arthritis and ankylosing spondylitis (Canon et al., 2006). However, diclofenac treatment may be accompanied by adverse side effects such as gastrointestinal damage, platelet dysfunction and convulsions. These effects are likely associated with the ability of phenyl acetic acid derivative to compete with arachidonic acid for binding to cyclooxygenase (COX), resulting in decreased prostaglandin formation (Vane, 1996 \& Liu et al., 2005).

Natural plant products have been used throughout human history for various purposes. Having coevolved with life, these natural products are billions of years old. Tens of thousands of them are produced as secondary metabolites by the higher plants as a natural defense against disease and infection. Medicines derived from plants have played a pivotal role in the health care of many cultures, both ancient and modern (Newman et al., 2003 and Newman \& Cragg, 2007). There is an increasing interest in beneficial chemicals derived from plants, known as phytochemicals. Dietary substances that provide medical or health benefits are termed "nutraceuticals". Polyphenols are the most abundant chemical substances considered nutraceuticals. Polyphenols are found in dark chocolate, peanuts, green and black tea, red wine, olive oil and the spice turmeric (Schaffer et al., 2010).

Turmeric (the common name for Curcuma longa) is an Indian spice derived from the rhizomes of the plant and has a long history of use in Ayurvedic medicine as a treatment for inflammatory conditions (Jurenka, 2009). Curcumin, the principal curcuminoid found in turmeric, is generally considered its most active constituent (Akram et al., 2010).

Quercetin is a naturally-occurring flavonol (a member of the flavonoid family of compounds) that has a long history of consumption as part of the normal human diet. Because a number of biological properties of quercetin may be beneficial to human health, interest in the addition of this flavonol to various traditional food products has been increasing (Harwood et al., 2007). 
The aim of the current study focused on the possible ability of diclofenac in limiting inflammation and joint cartilage erosion in an experimental model of arthritis rats. Because current treatments for arthritis result in unwanted side effects and tend to be expensive, the current work is also focused on the therapeutic effects of curcumin or/and quercetin dependent on time of treatment. Natural products devoid of such disadvantages offer a novel opportunity. Thus, the current work is a detailed discussion of the potential of natural agents for treatment of arthritis.

\section{Material and Methods}

This study was carried out on adult male albino rats (Rattus rattus) with 10 - 12 weeks old to induce arthritis the animal were injected with $150 \mu$ pristane $(2,6,10,14-$ tetramethylpentadecane) intradermally, the dose was divided and given at two injection sites at the base of the tail (Vingsbo et al., 1996). After ten days from injection, arthritis appeared as inflammation and swelling in the ankle or/and wrist joint. The midfoot or/and midforepaw (as extensor region) was also swollen.

In the second experiment, five comparisons were made between normal control rats and another four animal groups were suffered from arthritis. The $1^{\text {st }}$ group of them was injected intramuscular with diclofenac $(5 \mathrm{mg} / 100 \mathrm{~g} \mathrm{~b} . w \mathrm{t} / \mathrm{d})$ for 1,2 and 4 weeks. The $2^{\text {nd }}$ group was treated with diclofenac and administrated orally $100 \mathrm{mg}$ commercial curcumin / $100 \mathrm{~g}$ b.wt. (Sigma Chem. Co., St Louis, Mo. U.S.A) for 1,2 and 4 weeks. The $3^{\text {rd }}$ animal group was treated with both diclofenac and administrated orally $100 \mathrm{mg}$ quercetin $/ \mathrm{g}$ b.wt. (MEPACo, Egypt) for the same pervious intervals. The last animal group ( $4^{\text {th }}$ arthritis animal group) treated with diclofenac, curcumin and quercetin as described before for the same times.

Ten rats from each group were randomly selected at the end of each interval; autopsies were performed by inhalation anaesthesia with diethyl ether (Prolabo, El Nasr Pharma Co.). Blood was collected in dry clean test tube and left to clot. Sera were separated and cartilage samples were collected and frozen for measurement of physiological and biochemical parameters.

\section{Estimation of serum biochemical parameters:}

The levels of serum rat C-reactive protein (CRP), interleukin-1 $\alpha$ (IL-1 $\alpha$ ), interleukin-6 (IL-6), tumor necrosis factor- $\alpha(\mathrm{TNF}-\alpha)$, total antioxidant capacity (TAC), total oxidative capacity (TOC), total nitric oxide (TNO) and resistin were estimated using enzyme immunoassay (EIA) techniques (IBL Gesellschaft, Hamburg, Germany).

\section{Determination of tissue studies:}

Samples of knee joint cartilage were obtained at the end of each experimental period and wash with saline solution $(0.9 \% \mathrm{NaCl})$. After washing, these samples were homogenized in ice-cold $0.25 \mathrm{M}$ sucrose containing $1 \mathrm{mM}$ diethylenetriamine penta-acetic acid $(1: 1 \mathrm{w} / \mathrm{v})$. Each sample was then centrifuged for $20 \mathrm{~min}$ at $20,000 \mathrm{~g}$ and $4{ }^{\circ} \mathrm{C}$. The supernatant was aspirated and the levels of prostaglandin $\mathrm{E}_{2}\left(\mathrm{PGE}_{2}\right)$ and malondaldhyde (MDA) as well as the activities of cyclooxygenase-2 (COX-2) and lipoxygenase (LPO) were assayed by ELISA technique using commercial kits (IBL Co., Ltd.). 


\section{Statistic analysis:}

Statistical difference between the means was assayed by the Student's " $t$ " test for comparison between normal and arthritic rats group experiment. Two Way Analysis (ANOVA) followed by Duncan's multiple range test was used in the second experiment according to Duncan (1955) and Snedecor \& Corchan (1982).

\section{Results and Discussion}

Table (1) illustrated the changes in the immunological profile parameters. CRP, rat IL$1 \alpha$, rat IL- 6 , and rat TNF- $\alpha$ were elevated as a result of arthritis induction in rats by pristine injection. These results may be attributed to, RA is an autoimmune disease that is characterized by synovial lining proliferation, excessive angiogenesis, the accumulation of mononuclear cells in the synovium (Kramer et al, 2003) and a paucity of apoptosis (Mountz \& Zhang, 2001). T and B lymphocytes and macrophages infiltrate the affected synovial tissues, and promote the release of high concentrations of pro-inflammatory cytokines, including TNF- $\alpha$ and IL- 1 . In response to these cytokines, the synovial fibroblasts proliferate vigorously and form pangs tissues, which destroy the cartilage and bone of the joints (Meinecke et al., 2005).

Table (1): Changes in the serum cytokines levels (CRP, IL-1 $\alpha$, IL-6 and TNF- $\alpha$ ) in arthritic rats compared to their corresponding normal control rats.

\begin{tabular}{|c|c|c|c|}
\hline Parameters Groups & Normal group & Arthritic group & \% \\
\hline \hline CRP $(\mathrm{ng} / \mathrm{ml})$ & $6.98 \pm 0.148$ & $34.06^{*} \pm 0.923$ & $388.20 \%$ \\
\hline IL-1 $\boldsymbol{\alpha}(\mathrm{pg} / \mathrm{ml})$ & $4.11 \pm 0.112$ & $20.36^{*} \pm 0.714$ & $395.64 \%$ \\
\hline IL-6 $(\mathrm{pg} / \mathrm{ml})$ & $8.70 \pm 0.187$ & $31.72 * \pm 0.887$ & $264.85 \%$ \\
\hline TNF- $\boldsymbol{\alpha}(\mathrm{pg} / \mathrm{ml})$ & $5.07 \pm 0.083$ & $24.14^{*} \pm 0.825$ & $375.74 \%$ \\
\hline
\end{tabular}

- Data are expressed as mean \pm standard error (SE).

- (*) refer to high significance $(\mathrm{P}<0.001)$.

- \% of change from treated animal groups to control in the same row.

Several researches do not know exactly why RA develops. They speculate that a combination of factors including genetic susceptibility, abnormal immune response and certain changes in the body such as an infection or hormonal shift can trigger the development of RA (Lee and Weinblatt, 2001 and Yen et al., 2001). Infection by microbes, their products or injured endogenous cells will induce an inflammatory reaction, initially by interacting with pattern recognition receptors expressed on mast cell monocytes, macrophages and other cells of the innate immune system. These $\mathrm{T}$ (toll-like) receptors and Nod-like receptors transduce intracellular signals leading to the production and release of cytokines, eicosanoids and other inflammatory molecules that directly mediate cellular responses causing inflammation and recruiting all types of white blood cell to the site (Huston \& Tracey, 2011). There for the most important role of cytokines in the development of an inflammatory state is the recruitment of white blood cells to the site of inflammation. The other functions have been attributed to the chemokines network such as angiogenesis, modulation of the immune response and fever (Baggiolini, 2001).

Arthritis progression may be due to hyperplasia of the synovial lining. Although, the reason for the hyperplasia of the synovial lining in RA is not completely understood, impaired apoptosis or senescence has been proposed as a mechanism to explain their increased numbers. 
Therefore, the stimulation of apoptosis of the synovial fibroblasts may be useful for treating RA (Baier et al., 2003).

Table (2): Changes in the serum biochemical parameters (TAC, TOC, TNO and resistin) in arthritic rats compared to their corresponding normal control rats.

\begin{tabular}{|c|c|c|c|}
\hline Parameters Groups & Normal group & Arthritic group & \% \\
\hline \hline TAC $(\mathrm{m} \mathrm{mol} / \mathrm{L})$ & $1.60 \pm 0.083$ & $0.87^{*} \pm 0.051$ & $-45.59 \%$ \\
\hline \hline TOC $(\mathrm{m} \mathrm{mol} / \mathrm{L})$ & $0.26 \pm 0.007$ & $1.05^{*} \pm 0.038$ & $301.92 \%$ \\
\hline TNO $(\mathrm{m} \mathrm{mol} / \mathrm{L})$ & $43.79 \pm 1.396$ & $92.65^{*} \pm 3.694$ & $111.58 \%$ \\
\hline Resistin $(\mathrm{ng} / \mathrm{ml})$ & $3.50 \pm 0.041$ & $7.7 *^{*} \pm 0.112$ & $120.42 \%$ \\
\hline
\end{tabular}

- Data are expressed as mean \pm standard error (SE).

- (*) refer to high significance $(\mathrm{P}<0.001)$.

- \% of change from treated animal groups to control in the same row.

Table (2) showed that the level of serum TAC was considerable decreased while the levels of serum TOC, TNO and resistin were significantly increased in arthritic groups. These results may be attributed to low intake of major antioxidant nutrients and/or a redox balance shift towards the excessive production of ROS which might be a possible contributing factor. Similar results have been observed in other studies showing lower significant in the serum level of antioxidant nutrients, a considerable decrease in the antioxidant enzymes activities and a marked elevation in the blood oxidative stress markers in RA patients compared to those of their healthy counterparts (Firuzi et al., 2006 and Bae, 2009). Excess ROS not properly eliminated accelerate inflammatory responses thereby aggravate the disease (Bubici et al., 2006).

The overexpression in the NO production in arthritic rats may be attributed to a variety of immunological stimuli including pro-inflammatory cytokines inducing the expression of inducible nitric oxide synthase (iNOS) in a number of non-hematopoietic cells, including fibroblasts. The induction of iNOS may have either a toxic or a protective effect. In arthritis, NO induces the production of pathogenic cytokines such as TNF- $\alpha$ and IL- $1 \alpha$, in addition to certain chemokines that contribute to the disease progression in arthritis.

Although, resistin was first postulated to contribute to insulin resistance, it has recently been shown that resistin can trigger a proinflammatory state "in vitro" as well as "in vivo" (Bokarewa et al., 2005 and Filková et al., 2009). Despite the numerous recent studies concerning resistin pathophysiology, little is known about how resistin acts in the process of inflammation (Patel et al., 2003). Many authors demonstrated that upregulated in serum level of resistin and released by mononuclear leukocytes may be due to following proinflammatory stimuli such as TNF- $\alpha$, IL-1 $\alpha$, IL-6, lipopolysaccharide (LPS) and endotoxin which can strongly increase the expression of resistin in peripheral blood mononuclear cells (PBMCs), suggesting a role for resistin in the process of inflammation (Kaser et al., 2003; Lehrke et al., 2004 and Anderson et al., 2007). In addition, CRP induced both mRNA expression and protein secretion of resistin in a dose- and time-dependent manner in PBMCs (Bokarewa et al., 2005 and $\mathrm{Hu}$ et al., 2007). 
Table (3): Changes in knee cartilage parameters (PGE2, COX-2, MDA and Resistin) in arthritic rats compared to their corresponding normal control rats.

\begin{tabular}{|c|c|c|c|}
\hline Parameters Groups & Normal group & Arthritic group & \% \\
\hline \hline PGE $_{2}(\mathrm{pg} / \mathrm{mg})$ & $543.32 \pm 7.609$ & $1279.61 *_{ \pm}+19.837$ & $135.52 \%$ \\
\hline COX-2 $(\mathrm{ng} / \mathrm{g})$ & $4.837 \pm 0.136$ & $18.1 *_{ \pm} 1.105$ & $276.10 \%$ \\
\hline LPO $(\mathrm{pg} / \mathrm{ml})$ & $50.471 \pm 1.194$ & $172.8 *_{ \pm} \pm 3.069$ & $242.43 \%$ \\
\hline MDA $(\mathrm{n} \mathrm{mol} / \mathrm{g})$ & $0.171 \pm 0.006$ & $0.5 *_{ \pm} \pm .037$ & $240.94 \%$ \\
\hline Resistin $(\mathrm{ng} / \mathrm{mg})$ & $0.649 \pm 0.019$ & $1.61 *_{ \pm} 0.093$ & $148.69 \%$ \\
\hline
\end{tabular}

- Data are expressed as mean \pm Standard Error (SE).

$-(*)$ refer to high significance $(\mathrm{P}<0.001)$.

- $\%$ of change from treated animal groups to control in the same row.

From table (3) demonstrated that knee cartilage levels of $\mathrm{PGE}_{2}, \mathrm{COX}-2, \mathrm{LPO}, \mathrm{MDA}$ and resistin were significantly $(\mathrm{p}<0.001)$ increased in arthritic group compared to normal control animals. These data may be attributed to the action of phospholipase $\mathrm{A}_{2}\left(\mathrm{PLA}_{2}\right)$ which hydrolyzes the fatty acid from the sn-2 position of membrane phospholipids. Free fatty acids thus released can be metabolized to various lipid mediators of biological importance. As arachidonic acid is the precursor of eicosanoids, PLA $_{2}$ represents the central enzyme involved in the generation of eicosanoids and hence, is the mediator of many inflammatory processes, including RA. The release of inflammatory lipid mediators, particularly PGE2, thromboxane A2 (TXA2) and leukotriene B4 (LTB4) is regulated by a cascade of reactions starting from PLA2 (Venkatesha et al., 2011).

Table (4-6) revealed that amelioration effects of the diclofenac alone or with curcumin or quercetin and both antioxidants on the tested parameters in the serum knee cartilage of arthritic rats. A significant correction occurred in all immunological and biochemical parameters as a result of administration of diclofenac alone and diclofenac with curcumin and/or quercetin to arthritic rats groups depending on the time of treatment. The maximum correction in all studies parameters was obtained in the arthritic rats group which treated with both antioxidants (Curcumin and quercetin) in the presence of diclofenac dependent on the time of treatment.

NSAIDs are frequently used to treat rheumatoid arthritis because of their analgesic and anti-inflammatory activities. NSAIDs achieve their effect by blocking the activity of COX. COX is a key enzyme in catalyzing the conversion of arachidonic acid, which is released from the cell membrane, into prostaglandin (Moalic et al., 2001 and Kutuk \& Basaga, 2003). But, the regular use of NSAIDs induced adverse effects on gastrointestinal and cardiovascular system. In addition to reducing the fever and pain of inflammation, NSAIDs also inhibit blood clotting via interfering with the synthesis of thromboxane A2 in platelets (Siew and chan 2010). 
Table (4): Amelioration effects of the administration of diclofenac alone or with curcumin or/and quercetin on the CRP, IL-1 $\alpha$, Il-6 and TNF- $\alpha$ levels in arthritic rats.

\begin{tabular}{|c|c|c|c|c|c|c|}
\hline \multirow{5}{*}{$\underline{\underline{v}}$} & & \multirow{2}{*}{$\begin{array}{c}\text { Normal } \\
\text { group }\end{array}$} & \multicolumn{4}{|c|}{ Diclofenac } \\
\hline & & & Alone & Curcumin & Quercetin & Mixture \\
\hline & 1 week & $6.9 \pm 0.15^{\mathrm{A}}$ & $29.38 \pm 0.86^{\mathrm{B}}{ }_{\mathrm{a}}$ & $22.74 \pm 0.75^{\mathrm{C}}$ & $25.32 \pm 0.80^{\mathrm{D}}{ }_{\mathrm{a}}$ & $20.65 \pm 0.68^{\mathrm{E}}$ \\
\hline & 2 weeks & $6.96 \pm 0.15^{\mathrm{A}}$ & $21.82 \pm 0.71_{b}^{\mathrm{B}}$ & $15.87 \pm 0.51_{b}^{\mathrm{C}}$ & $18.33 \pm 0.52^{D}{ }_{b}$ & $13.56 \pm 0.48^{\mathrm{E}}{ }_{\mathrm{b}}$ \\
\hline & 4 weeks & $6.93 \pm 0.15_{\mathrm{a}}^{\mathrm{A}}$ & $16.06 \pm 0.53^{\mathrm{B}}{ }_{\mathrm{c}}$ & $10.10 \pm 0.35^{C}{ }_{c}$ & $14.62 \pm 0.49^{\mathrm{D}}{ }_{\mathrm{c}}$ & $8.85 \pm 0.35^{\mathrm{E}}{ }_{\mathrm{c}}^{\mathrm{c}}$ \\
\hline \multirow{3}{*}{$\frac{8}{b}$} & 1 week & $4.09 \pm 0.11_{\mathrm{a}}^{\mathrm{A}}$ & $18.54 \pm 0.88^{\mathrm{B}}{ }_{\mathrm{a}}$ & $15.91 \pm 0.74^{\mathrm{C}}$ & $16.02 \pm 0.74^{\mathrm{C}}$ & $13.38 \pm 0.67^{\mathrm{D}}$ \\
\hline & 2 weeks & $4.11 \pm 0.11^{\mathrm{A}}{ }_{\mathrm{a}}$ & $16.72 \pm 0.78_{b}^{B}$ & $13.29 \pm 0.67_{b}^{C}$ & $13.41 \pm 0.67_{b}^{C}$ & $11.89 \pm 0.60_{b}^{\mathrm{D}}$ \\
\hline & 4 weeks & $4.13 \pm 0.14_{\mathrm{a}}^{\mathrm{A}}$ & $13.92 \pm 0.69^{\mathrm{B}}{ }_{\mathrm{c}}$ & $10.56 \pm 0.55^{\mathrm{C}}{ }_{\mathrm{c}}$ & $10.46 \pm 0.54^{\mathrm{C}}{ }_{\mathrm{c}}$ & $8.82 \pm 0.47_{c}^{D_{c}}$ \\
\hline \multirow{3}{*}{${ }^{0}$} & 1 week & $8.68 \pm 0.18_{a}^{A}$ & $30.94 \pm 0.87^{\mathrm{B}}$ & $27.34 \pm 0.80^{C}$ & $26.99 \pm 0.84^{\mathrm{C}}$ & $25.89 \pm 0.79^{D}$ \\
\hline & 2 weeks & $8.73 \pm 0.19^{A}{ }_{a}$ & $27.65 \pm 0.83^{\mathrm{B}}$ & $24.63 \pm 0.73_{b}^{C}$ & $24.19 \pm 0.79^{C}$ & $19.56 \pm 0.41_{b}^{\mathrm{D}}$ \\
\hline & 4 weeks & $8.71 \pm 0.19_{a}^{\mathrm{A}}$ & $23.18 \pm 0.63^{\mathrm{B}}$ & $20.39 \pm 0.49^{C}{ }_{c}$ & $21.67 \pm 0.58^{\mathrm{D}}{ }_{\mathrm{c}}$ & $16.84 \pm 0.38^{\mathrm{E}}{ }_{\mathrm{c}}$ \\
\hline \multirow{3}{*}{ 竞 } & 1 week & $5.11 \pm 0.09_{\mathrm{a}}^{\mathrm{A}}$ & $29.56 \pm 0.82^{\mathrm{B}}{ }_{\mathrm{a}}$ & $26.18 \pm 0.70_{a}^{C}$ & $27.69 \pm 0.76_{a}^{D}$ & $24.34 \pm 0.66_{\mathrm{a}}^{\mathrm{E}}$ \\
\hline & 2 weeks & $5.09 \pm 0.08^{\mathrm{A}}{ }_{\mathrm{a}}$ & $25.79 \pm 0.68_{b}^{\mathrm{B}}$ & $21.65 \pm 0.54_{b}^{C}$ & $23.82 \pm 0.59^{\mathrm{D}}{ }_{b}$ & $19.94 \pm 0.51^{\mathrm{E}}$ \\
\hline & 4 weeks & $5.05 \pm 0.08^{\mathrm{A}}{ }_{\mathrm{a}}$ & $22.56 \pm 0.54_{c}^{\mathrm{B}}$ & $16.03 \pm 0.38^{C}{ }_{c}$ & $18.19 \pm 0.42^{\mathrm{D}}{ }_{\mathrm{c}}$ & $13.72 \pm 0.29^{\mathrm{E}}{ }_{\mathrm{c}}$ \\
\hline
\end{tabular}

- Data are expressed as mean \pm standard error (SE).

- A, B, C and D are different superscripts with in the same row are significantly different at $\mathrm{p}<0.05$.

$-\mathrm{a}, \mathrm{b}$ and $\mathrm{c}$ are different subscripts with in the same column are significantly different $\mathrm{P}<0.05$.

During severe infection or after severe injury, excessive synthesis and production of proinflammatory cytokines, including TNF- $\alpha$, IL-1 $\alpha$ and IL-6, play `a major role in the development of local and systemic inflammation, causing severe pathophysiological derangement or organ failure (Munford \& Pugin, 2001). Inhibition of pro-inflammatory cytokine production by regulation of transcriptional factors, such as $\mathrm{NF}-\kappa \mathrm{B}$, is a potential strategy for controlling inflammatory responses (Tak \& Firestein, 2001).

Curcumin and quercetin potently inhibit the activation of some transcription factors including nuclear factor- $\kappa \mathrm{B}(\mathrm{NF}-\kappa \mathrm{B})$, activated protein-1 (AP-1) (Dhandapani et al., 2007), signal transducer and activator of transcription (STAT) proteins (Bhattacharyya et al., 2007), Notch-1(Wang et al., 2006), early growth response-1 (Egr-1) (Chen et al., 2006) and $\beta$ catenin (Prasad et al., 2009). NF- $\mathrm{kB}$, representing a family of eukaryotic transcription factors, plays an essential role in regulating the expression of a wide range of genes critical for innate and adaptive immunity, inflammation and cell survival (Hayden \& Ghosh, 2008).

Various pathogenic stimuli, including bacterial products, carcinogens, tumour promotors, cytokines, radiation, ischemia/reperfusion, and oxidants can activate NF- $\mathrm{B}$ via several signal transduction pathways. Upon activation, NF- $\kappa \mathrm{B}$ is translocated to the nucleus, where it induces the expression of more than 200 target genes that have been shown to induce cell proliferation, invasion, metastasis, chemoresistance, and/or inflammation (Zhou et al., 2011).

Curcumin's inhibition of inflammatory cytokines is achieved through a number of mechanisms. In vitro studies indicate that curcumin regulates activation of certain transcription factors such as activating protein-1 (AP-1) and NF- $\mathrm{-B}$ in stimulated monocytes and alveolar macrophages, thereby blocking expression of cytokine gene expression. Down-regulation of intercellular signalling proteins, such as protein kinase $\mathrm{C}$ may be another way in which curcumin inhibits cytokine production (Jurenka, 2009). 
Table (5): Amelioration effects of the administration of diclofenac alone or with curcumin or/and quercetin on the TAC, TOC, TNO and resistin levels in arthritic rats.

\begin{tabular}{|c|c|c|c|c|c|c|}
\hline \multirow{5}{*}{$\underset{\xi}{U}$} & & \multirow{2}{*}{$\begin{array}{l}\text { Normal } \\
\text { group }\end{array}$} & \multicolumn{4}{|c|}{ Diclofenac } \\
\hline & & & Alone & Curcumin & Quercetin & Mixture \\
\hline & 1 week & $1.62 \pm 0.08_{a}^{\mathrm{A}}$ & $0.86 \pm 0.06^{\mathrm{B}}{ }_{\mathrm{b}}$ & $0.97 \pm 0.05^{\mathrm{C}}$ & $0.97 \pm 0.05^{\mathrm{C}}$ & $1.11 \pm 0.06_{a}^{\mathrm{D}}$ \\
\hline & 2 weeks & $1.63 \pm 0.08_{a}^{\mathrm{A}}$ & $0.85 \pm 0.05^{\mathrm{B}}$ & $1.13 \pm 0.07_{b}^{\mathrm{C}}$ & $1.10 \pm 0.06_{b}^{\mathrm{C}}$ & $1.27 \pm 0.07_{b}^{\mathrm{D}}$ \\
\hline & 4 weeks & $1.60 \pm 0.08^{\mathrm{A}}{ }_{\mathrm{a}}$ & $0.97 \pm 0.06^{\mathrm{B}}$ & $1.32 \pm 0.08_{c}^{C}$ & $1.25 \pm 0.07_{\mathrm{c}}^{\mathrm{D}}$ & $1.51 \pm 0.09^{\mathrm{E}}$ \\
\hline \multirow{3}{*}{ ๖ } & 1 week & $0.24 \pm 0.01_{\mathrm{a}}^{\mathrm{A}}$ & $1.05 \pm 0.042^{\mathrm{B}}{ }_{\mathrm{a}}$ & $0.82 \pm 0.03^{\mathrm{C}}$ & $0.82 \pm 0.03^{\mathrm{C}}{ }_{\mathrm{a}}$ & $0.75 \pm 0.03^{\mathrm{D}}{ }_{\mathrm{a}}$ \\
\hline & 2 weeks & $0.26 \pm 0.00^{\mathrm{A}}{ }_{\mathrm{a}}$ & $1.04 \pm 0.04^{\mathrm{B}}$ & $0.66 \pm 0.03^{\mathrm{C}}{ }_{\mathrm{b}}$ & $0.66 \pm 0.03_{b}^{C}$ & $0.52 \pm 0.21_{b}^{\mathrm{D}}$ \\
\hline & 4 weeks & $0.26 \pm 0.01_{\mathrm{a}}^{\mathrm{A}}$ & $0.96 \pm 0.04^{\mathrm{B}}{ }_{\mathrm{b}}$ & $0.48 \pm 0.02^{\mathrm{C}}{ }_{\mathrm{c}}$ & $0.55 \pm 0.02^{\mathrm{D}}{ }_{\mathrm{c}}$ & $0.35 \pm 0.01_{c}^{\mathrm{E}}$ \\
\hline \multirow{3}{*}{$\stackrel{\bigcirc}{Z}$} & 1 week & $44.02 \pm 1.41^{\mathrm{A}}{ }_{\mathrm{a}}$ & $82.67 \pm 3.09^{\mathrm{B}}{ }_{\mathrm{a}}$ & $75.19 \pm 2.48^{C}$ & $78.54 \pm 2.71_{a}^{\mathrm{D}}$ & $70.83 \pm 2.20^{\mathrm{E}}{ }_{\mathrm{a}}$ \\
\hline & 2 weeks & $43.84 \pm 1.41^{\mathrm{A}}{ }_{\mathrm{a}}$ & $76.54 \pm 2.56^{\mathrm{B}}{ }_{\mathrm{b}}$ & $68.27 \pm 2.06^{\mathrm{C}}$ & $74.8 \pm 2.37^{\mathrm{D}}$ & $62.38 \pm 2.01^{\mathrm{E}}{ }_{\mathrm{b}}$ \\
\hline & 4 weeks & $44.23 \pm 1.42^{\mathrm{A}}{ }_{\mathrm{a}}$ & $70.29 \pm 2.15^{\mathrm{B}}{ }_{c}$ & $60.92 \pm 1.94^{\mathrm{C}}$ & $66.73 \pm 2.10^{\mathrm{D}}$ & $53.91 \pm 1.89^{\mathrm{E}}{ }_{\mathrm{c}}$ \\
\hline \multirow{3}{*}{ 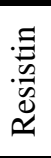 } & 1 week & $3.47 \pm 0.04^{\mathrm{A}}$ & $7.10 \pm 0.10_{a}^{\mathrm{B}}$ & $7.04 \pm 0.09^{\mathrm{B}}$ & $7.06 \pm 0.09^{\mathrm{B}}$ & $7.01 \pm 0.09^{\mathrm{B}}$ \\
\hline & 2 weeks & $3.51 \pm 0.04^{\mathrm{A}}$ & $6.58 \pm 0.07^{\mathrm{B}}{ }_{\mathrm{b}}$ & $6.12 \pm 0.06_{b}^{C}$ & $6.53 \pm 0.07^{\mathrm{B}}{ }_{\mathrm{b}}$ & $5.14 \pm 0.06^{\mathrm{D}}{ }_{\mathrm{b}}$ \\
\hline & 4 weeks & $3.52 \pm 0.04^{\mathrm{A}}$ & $5.90 \pm 0.06^{\mathrm{B}}$ & $4.54 \pm 0.04^{\mathrm{C}}$ & $5.22 \pm 0.05^{\mathrm{D}}$ & $4.01 \pm 0.05_{c}^{\mathrm{E}}$ \\
\hline
\end{tabular}

- Data are expressed as mean \pm standard error (SE).

- A, B, C and D are different superscripts with in the same row are significantly different at $\mathrm{p}<0.05$.

$-\mathrm{a}, \mathrm{b}$ and $\mathrm{c}$ are different subscripts with in the same column are significantly different $\mathrm{P}<0.05$.

The oxidant and antioxidant paremeters were also enhancement after diclofenac, curcumin or quercetin treatment (Table 5). COX-2-expression and NO generation are regulated by activation of the ubiquitous transcription factor NF-kB (Liacini et al., 2002). In the inactive state, the p65 subunit of NF-kB is retained in the cytoplasm, but when NF-kB is activated, the phosphorylated p65 subunit of NF-kB translocates to the nucleus, where it binds to consensus regulatory DNA sequences directly regulating gene expression or trans-activating other transcription factors that possess NF-kB binding sites (Grall et al., 2003). Thus, it is possible that curcumin suppresses COX-2 and iNOs expression by inhibiting NF-K $\beta$ activation (Rahman et al., 2006). Curcumin and quercetin inhibited both IL-1 $\alpha$-induced NF-kB activation by phosphorylation of p65 and phosphorylation of NFkB inhibitor $\alpha$ (IkBa) which, in turn, lead to its degradation and consequently to the release of activated NF-kB (Shakibaei et al., 2007 and Qureshi et al., 2011).

Jung \& Sung (2004) showed that dietary antioxidants effectively suppress the release of inflammatory cytokines by reducing available ROS. The health benefits of polyphenols during oxidative stress are due to its antioxidant and free radical scavenger effect (Rahman et al., 2006). Curcumin (in the micro to millimolar range) was shown to scavenge ROS, such as superoxide anion $\left(\mathrm{O}_{2}\right)$, hydrogen peroxide $\left(\mathrm{H}_{2} \mathrm{O}_{2}\right)$ and nitric oxide $(\mathrm{NO})$, both in vitro and in vivo. The antioxidant properties of curcumin are based on its lipid peroxidation lowering effects through its ability to maintain the cellular status of antioxidant enzymes like superoxide dismutase, catalase and glutathione peroxidase (Mahakunakorn et al., 2003).

On the other hand, flavonoids are known to display many antioxidant properties including scavenging free radicals and preventing lipid peroxidation (Rotelli et al., 2003). The antioxidant properties of these molecules (polyphenols) were later explained on the basis of the availability of $\mathrm{OH}$ and the system of conjugated double bonds present in these molecules. However, many other effects of polyphenols such as anti-inflammatory, anti-tumour, antiatherogenic abilities could not be explained solely on the basis of their antioxidant properties. 
Investigations into the mechanism of action of these molecules have thrown light on the fact that polyphenols may not merely exert their effects as free radical scavengers, but may also modulate cellular signalling processes during inflammation or may themselves serve as signalling agents (Aggarwal and Shisodia, 2004).

The significant $(\mathrm{p}<0.05)$ changes in the tissue levels of PGE2, COX-2, LPO, MDA and resistin in arthritic rats after receiving diclofenac, curcumin or quercetin were recorded in table Table (6). These results may be due to several polyphenols such as curcumin and quercetin inhibited COX-2, iNOS, 5-LOX, 12-LOX and phospholipase A2 (PLA2) activities (Zhou et al., 2011 and Yoon \& Baek, 2005). The ability of curcumin and quercetin to induce the efficient arrest cell proliferation and cell death in a variety of tumour cells may be another cause (Cheng et al., 2010).

Table (6): Amelioration effects of the administration of diclofenac alone or with curcumin or/and quercetin on the PGE2, COX-2, LPO, MDA and resistin levels in arthritic rats tissue.

\begin{tabular}{|c|c|c|c|c|c|c|}
\hline \multirow{5}{*}{ 㐾 } & & \multirow{2}{*}{$\begin{array}{l}\text { Normal } \\
\text { group }\end{array}$} & \multicolumn{4}{|c|}{ Diclofenac } \\
\hline & & & Alone & Curcumin & Quercetin & Mixture \\
\hline & 1 week & $540.62 \pm 7.60^{\mathrm{A}}{ }_{\mathrm{a}}$ & $1002.54 \pm 17.32^{\mathrm{B}}{ }_{\mathrm{a}}$ & $824.32 \pm 16.26^{\mathrm{C}}{ }_{\mathrm{a}}$ & $901.77 \pm 16.82^{\mathrm{D}}{ }_{\mathrm{a}}$ & $724.08 \pm 14.32^{\mathrm{E}}$ \\
\hline & 2 weeks & $547.09 \pm 7.59^{\mathrm{A}}{ }_{\mathrm{a}}$ & $861.49 \pm 16.63^{\mathrm{B}}{ }_{\mathrm{b}}$ & $749.38 \pm 14.82^{\mathrm{C}}{ }_{\mathrm{b}}$ & $811.64 \pm 15.88^{\mathrm{D}}{ }_{\mathrm{b}}$ & $618.59 \pm 11.92^{\mathrm{E}}{ }_{\mathrm{b}}$ \\
\hline & 4 weeks & $551.34 \pm 7.63^{\mathrm{A}}{ }_{\mathrm{a}}$ & $667.81 \pm 13.463^{\mathrm{B}}{ }_{\mathrm{c}}$ & $602.72 \pm 554.12^{\mathrm{C}}{ }_{\mathrm{c}}$ & $611.63 \pm 12.03^{\mathrm{C}}{ }_{\mathrm{c}}$ & $557.36 \pm 10.23^{D_{c}}$ \\
\hline \multirow{3}{*}{ ญ̇ } & 1 week & $4.86 \pm 0.142^{\mathrm{A}}$ & $15.05 \pm 1.04^{\mathrm{B}}{ }_{\mathrm{a}}$ & $13.39 \pm 0.86_{\mathrm{a}}^{\mathrm{C}}$ & $14.43 \pm 0.95_{\mathrm{a}}^{\mathrm{D}}$ & $12.19 \pm 0.81_{\mathrm{a}}^{\mathrm{E}}$ \\
\hline & 2 weeks & $4.853 \pm 0.14_{\mathrm{a}}^{\mathrm{A}}$ & $13.17 \pm 0.84_{b}^{\mathrm{B}}$ & $10.57 \pm 0.74_{b}^{C}$ & $11.49 \pm 0.78_{b}^{\mathrm{D}}$ & $8.94 \pm 0.68_{b}^{\mathrm{E}}$ \\
\hline & 4 weeks & $4.839 \pm 0.14_{\mathrm{a}}^{\mathrm{A}}$ & $10.52 \pm 0.71^{\mathrm{B}}{ }_{\mathrm{c}}$ & $7.87 \pm 0.54_{c}^{\mathrm{C}}$ & $8.69 \pm 0.64_{c}^{\mathrm{D}}$ & $5.83 \pm 0.48^{\mathrm{E}}$ \\
\hline \multirow{3}{*}{$\stackrel{0}{\beth}$} & 1 week & $50.63 \pm 1.23^{\mathrm{A}}$ & $150.39 \pm 2.85^{\mathrm{B}}{ }_{\mathrm{a}}$ & $131.76 \pm 2.37_{\mathrm{a}}^{\mathrm{C}}$ & $143.08 \pm 2.54_{\mathrm{a}}^{\mathrm{D}}$ & $118.54 \pm 2.06^{\mathrm{E}}$ \\
\hline & 2 weeks & $50.55 \pm 1.21_{\mathrm{a}}^{\mathrm{A}}$ & $127.61 \pm 2.16^{\mathrm{B}}{ }_{\mathrm{b}}$ & $100.53 \pm 1.93^{\mathrm{C}}{ }_{\mathrm{b}}$ & $114.92 \pm 2.04_{\mathrm{b}}^{\mathrm{D}}$ & $85.77 \pm 1.86^{\mathrm{E}}{ }_{\mathrm{b}}$ \\
\hline & 4 weeks & $50.56 \pm 1.21_{a}^{\mathrm{A}}$ & $105.58 \pm 0.00^{\mathrm{B}}{ }_{\mathrm{c}}$ & $77.92 \pm 1.58_{c}^{\mathrm{C}}$ & $83.61 \pm 1.69_{c}^{\mathrm{D}}$ & $68.47 \pm 0.1 .42^{\mathrm{E}}{ }_{\mathrm{c}}$ \\
\hline \multirow{3}{*}{$\stackrel{\mathbb{2}}{\stackrel{1}{\Sigma}}$} & 1 week & $0.168 \pm 0.01^{\mathrm{A}}{ }_{\mathrm{a}}$ & $0.573 \pm 0.042^{\mathrm{B}}{ }_{\mathrm{a}}$ & $0.512 \pm 0.03^{\mathrm{C}}{ }_{\mathrm{a}}$ & $0.514 \pm 0.03^{\mathrm{C}}{ }_{\mathrm{a}}$ & $0.481 \pm 0.03_{\mathrm{a}}^{\mathrm{D}}$ \\
\hline & 2 weeks & $0.173 \pm 0.00^{\mathrm{A}}{ }_{\mathrm{a}}$ & $0.524 \pm 0.031^{\mathrm{B}}{ }_{\mathrm{b}}$ & $0.462 \pm 0.03^{C}{ }_{b}$ & $0.471 \pm 0.03_{\mathrm{b}}^{\mathrm{C}}$ & $0.393 \pm 0.02^{\mathrm{D}}{ }_{\mathrm{b}}$ \\
\hline & 4 weeks & $0.169 \pm 0.01_{a}^{\mathrm{A}}$ & $0.473 \pm 0.03_{c}^{\mathrm{B}}$ & $0.351 \pm 0.02^{\mathrm{C}}{ }_{\mathrm{c}}$ & $0.392 \pm 0.02^{\mathrm{D}}{ }_{\mathrm{c}}$ & $0.294 \pm 0.01_{c}^{\mathrm{E}}$ \\
\hline \multirow{3}{*}{ 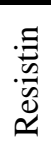 } & 1 week & $0.651 \pm 0.02^{\mathrm{A}}{ }_{\mathrm{a}}$ & $1.594 \pm 0.9_{\mathrm{a}}^{\mathrm{B}}$ & $1.401 \pm 0.08_{\mathrm{a}}^{\mathrm{C}}$ & $1.402 \pm 0.09_{\mathrm{a}}^{\mathrm{C}}$ & $1.369 \pm 0.08^{\mathrm{C}}{ }_{\mathrm{a}}$ \\
\hline & 2 weeks & $0.655 \pm 0.03^{\mathrm{A}}{ }_{\mathrm{a}}$ & $1.257 \pm 0.08^{\mathrm{B}}{ }_{\mathrm{b}}$ & $1.052 \pm 0.07_{\mathrm{b}}^{\mathrm{C}}$ & $1.061 \pm 0.06_{\mathrm{b}}^{\mathrm{C}}$ & $0.957 \pm 0.06^{\mathrm{D}}{ }_{\mathrm{b}}$ \\
\hline & 4 weeks & $0.648 \pm 0.02^{\mathrm{A}}{ }_{\mathrm{a}}$ & $1.018 \pm 0.06^{\mathrm{B}}{ }_{\mathrm{c}}$ & $0.841 \pm 0.05^{\mathrm{C}}$ & $0.856 \pm 0.05^{\mathrm{C}}$ & $0.793 \pm 0.03^{\mathrm{D}}{ }_{\mathrm{c}}$ \\
\hline
\end{tabular}

- Data are expressed as mean \pm standard error (SE).

- A, B, C and D are different superscripts with in the same row are significantly different at $\mathrm{P}<0.05$.

$-\mathrm{a}, \mathrm{b}$ and $\mathrm{c}$ are different subscripts with in the same column are significantly different $\mathrm{P}<0.05$.

Biochemical investigations of the flavonoid mechanisms of action have shown that these compounds inhibit a wide variety of enzymatic systems. The ability of certain flavonoids to inhibit both cyclooxygenase and 5-lipooxygenase pathways of the arachidonate metabolism may contribute to the anti-inflammatory properties (Rotelli et al., 2003). Curcumin may has the ability to decrease the expression levels of the COX-2 mRNA and protein without causing significant changes in the COX-1 levels, which was correlated with the inhibition of prostaglandin E2 synthesis (Park et al., 2007).

Arachidonic acid in cell membranes plays an important role in inflammatory responses by generating potent chemical messengers known as eicosanoids. Membrane phospholipids are hydrolyzed by phospholipase A2 (PLA2), releasing arachidonic acid, which may be metabolized by cyclooxygenases (COX), to form prostaglandins and thromboxane; or by 
lipoxygenases (LOX) to form leukotrienes. Curcumin has been found to inhibit PLA2, COX-2 and 5-LOX activities in cultured cells. Although, curcumin has been shown to inhibit the catalytic activity of the enzyme 5-LOX directly, it inhibited PLA2 by preventing its phosphorylation and COX-2 mainly by inhibiting its transcription. Nuclear factor-kappa B $(\mathrm{NF}-\mathrm{kB})$ is the transcription factor that enhances the transcription of the COX-2 gene and other pro-inflammatory genes (Henrotin et al., 2010).

Decrease in the level of MDA after the treatment with both curcumin and quercetin in the same time with diclofenac may be due to the ability of polyphenols to scavenger ROS. Scavenging ROS would not only prevent the occurrence of oxidative stress but also help mitigate inflammation (Nair et al., 2006). Due to antioxidants ability to scavenge free radicals and reactive species, thereby reducing oxidative stress and associated damage, various health claims have been made regarding the use of exogenous, dietary antioxidants (Blomhoff, 2005). Consequently, the use of exogenous antioxidants to support the treatment of these diseases, or may be even cure them, has gained a lot of interest recently (Vertuani et al., 2004).

From previous results, we can conclude that the combination between diclofenac and natural anti-inflammatory polyphenols are more effective in alleviating arthritis symptoms than can use NSAIDs only. The mixture group showed the maximum improvement after four weeks. Curcumin and quercetin in addition to their therapeutic role can block the undesirable effects for diclofenac. Therefore, using a mixture of curcumin and quercetin in the presence of diclofenac improves the pharmadynamics and pharmakinetic properties of diclofenac and also act together to decrease the harmful side effects of diclofenac. 


\section{References}

Aggarwal, B. B. and Harikumar, K. B. (2009): Potential therapeutic effects of curcumin, the anti-inflammatory agent, against neurodegenerative, cardiovascular, pulmonary, metabolic, autoimmune and neoplastic diseases. The International Journal of Biochemistry \& Cell Biology, 41: 40-59.

Aggarwal, B. B. and Shisodia, S. (2004): Suppression of the nuclear factorkappaB activation pathway by spice-derived phytochemicals: reasoning for seasoning. Ann NY Acad Sci., 1030: 434-441.

Akram, M.; Shahab-Uddin; Ahmed, A.; Usmanghani, K.; Hannan, A.; Mohiuddin, E. and Asif, M. (2010): Curcuma Longa and Curcumin: A Review Article. ROM. J. BIOL. PLANT BIOL, 55(2): 65-70.

Anderson, P. D.; Mehta, N. N.; Wolfe, M. L.; Hinkle, C. C.; Pruscino, L.; Comiskey, L. L.; Tabita-Martinez, J.; Sellers, K. F.; Rickels, M. R.; Ahima, R. S. and Reilly, M. P. (2007): Innate immunity modulates adipokines in humans, J. Clin. Endocrinol. Metab., 92: 2272-2279.

Bae, S. C. (2009): Effects of antioxidant supplements intervention on the level of plasma inflammatory molecules and disease severity of rheumatoid arthritis patients. Journal of the American College of Nutrition, 28 (1): 56-62.

Baggiolini, M. (2001): Chemokines in pathology and medicine. J Intern Med., 250 (2): 91104.

Baier, A.; Meineckel, I.; Gay, S. and Pap, T. (2003): Apoptosis in rheumatoid arthritis. Curr Opin. Rheumatol., 15: 274-329.

Bhattacharyya, S.; Mandal, D. and Saha, B. (2007): Curcumin prevents tumor-induced T cell apoptosis through Stat-5a-mediated Bcl-2 induction. J. Biol. Chem., 282: 15954-1564.

Blomhoff, R. (2005): Dietary antioxidants and cardiovascular disease. Curr. Opin. Lipidol., 16: 47-54.

Bokarewa, M.; Nagaev, I.; Dahlberg, L.; Smith, U. and Tarkowski, A. (2005): Resistin, an adipokine with potent proinflammatory properties, J. Immunol., 174: 5789-5795.

Bubici, C.; Papa, S.; Pham, C. G.; Zazzeroni, F. and Franzoso, G. (2006): The NF-kBmediated control of ROS and JNK signaling. Histol. Histopathol., 21: 69-80.

Chen, A.; Xu, J. and Johnson, A. C. (2006): Curcumin inhibits human colon cancer cell growth by suppressing gene expression of epidermal growth factor receptor through reducing the activity of the transcription factor Egr-1. Oncogene, 25: 278-287.

Chen, Y. F.; Jobanputra, P.; Barton, P.; Bryan, S.; Fry-Smith, A.; Harris, G. and Taylor, R. $S$. (2008): Cyclooxygenase-2 selective non-steroidal anti-inflammatory drugs (etodolac, meloxicam, celecoxib, rofecoxib, etoricoxib, valdecoxib and lumiracoxib) for osteoarthritis and rheumatoid arthritis: a systematic review and economic evaluation. Health Technol. Assess., 12 (1): 278-289.

Cheng, S.; Gao, N.; Zhang, Z.; Chen, G.; Budhraja, A. and Ke, Z. (2010): Quercetin induces tumor-selective apoptosis through downregulation of Mcl-1 and activation of Bax. Clin. Cancer Res., 16: 5679-5691.

Dhandapani, K. M.; Mahesh, V. B. and Brann, D. W. (2007): Curcumin suppresses growth and chemoresistance of human glioblastoma cells via AP-1 and NFkappaB transcription factors. J. Neurochem., 102: 522-538.

Duncan, D. B. (1955): Biometric., 11: 1- 42.

Filková, M.; Haluzik, M.; Gay, S. and Šenolt, L. (2009): The role of resistin as a regulator of inflammation: Implications for various human pathologies. Clinical Immunology, 133: 157-170. 
Firuzi, O.; Fuksa, L.; Spadaro, C.; Bousova, I.; Riccieri, V.; Spadaro, A.; Petrucci, R.; Marrosu, G. and Saso, L. (2006): Oxidative stress parameters in different systemic rheumatic diseases. J. Pharm. Pharmacol., 58: 951-957.

Ge, Z.; Hu, Y.; Heng, B. C.; Yang, Z.; Ouyang, H.; Lee, E. H. and Cao, T. (2006): Osteoarthritis and therapy. Arthritis Rheum., 55: 493-500.

Grall, F.; Gu, X.; Tan, L.; Cho, J. Y.; Inan, M. S. and Pettit; A. R. (2003): Responses to the proinflammatory cytokines interleukin-1 and tumor necrosis factor alpha in cells derived from rheumatoid synovium and other joint tissues involve nuclear factor kappaB-mediated induction of the Ets transcription factor ESE-1. Arthritis Rheum., 48: 1249-1260.

Harwood, M.; Danielewska-Nikiel, B.; Borzelleca, J. F.; Flamm, G. W.; Williams G. M. and Lines, T.C. (2007): A critical review of the data related to the safety of quercetin and lack of evidence of in vivo toxicity, including lack of genotoxic/carcinogenic properties. Food and Chemical Toxocology, 45: 2179-2205.

Hayden, M. S. and Ghosh, S. (2008): Shared principles in NF-kappaB signaling. Cell, 132: 344-362.

Henrotin, Y.; Clutterbuck, A.L.; Allaway, D.; Harris, P.; Mathy-Hartert, M.; Shakibaei, M. and Mobasheri, A. (2010): Biological Actions of Curcumin on Articular Chondrocytes. Osteoarthritis Cartilage, 18 (2): 141-149.

Hu, W. L.; Qian, S. B. and Li, J. J. (2007): Decreased C-reactive proteininduced resistin production in human monocytes by simvastatin. Cytokine, 40: 201-206.

Huston, J. M. and Tracey, K. J. (2011): The pulse of inflammation: heart rate variability, the cholinergic anti-inflammatory pathway and implications for therapy. J. Intern. Med., 269: 45-53.

Jung, W. J. and Sung, M. K. (2004): Effects of major dietary antioxidants on inflammatory markers of RAW 264.7 macrophages. Biofactors, 21:113-117.

Jurenka, J. S. (2009): Anti-inflammatory Properties of Curcumin, a Major Constituent of Curcuma longa: A Review of Preclinical and Clinical Research. Alternative Medicine Review, 14 (2): 141-153.

Kaser, S.; Kaser, A.; Sandhofer, A.; Ebenbichler, C. F.; Tilg, H. and Patsch, J. R. (2003): Resistin messenger-RNA expression is increased by proinflammatory cytokines in vitro. Biochem. Biophys. Res. Commun., 309: 286-290.

Khanna, D.; Sethi, G.; Ahn, K. S.; Pandey, M. K.; Kunnumakkara, A. B.; Sung, B. and Aggarwal, A.; Aggarwal, B. B. (2007): Natural Product as a Gold Mine for Arthritis Treatment. Curr. Opin. Pharmacol., 7: 344-351.

Kutuk, O. and Basaga, H. (2003): Aspirin prevents apoptosis and NF-kappa B activation induced by $\mathrm{H}_{2} \mathrm{O}_{2}$ in hela cells. Free Radical Research, 37: 1267-1276.

Lee, D. M. and Weinblatt, M. E. (2001): Rheumatoid arthritis. Lancet, 358: 903-911.

Lehrke, M.; Reilly, M. P.; Millington, S. C.; Iqbal, N.; Rader, D. J. and Lazar, M. A. (2004): An inflammatory cascade leading to hyperresistinemia in humans, PLoS Med., 1: 4557.

Liacini, A.; Sylvester, J.; Li, W. Q. and Zafarullah, M. (2002): Inhibition of interleukin-1stimulated MAP kinases, activating protein-1 (AP-1) and nuclear factor kappa B (NFkappa B) transcription factors down-regulates matrix metalloproteinase gene expression in articular chondrocytes. Matrix Biol., 21: 251-262.

Mahakunakorn, P.; Tohda, M.; Murakami, Y.; Matsumoto, K.; Watanabe, H. and Vajragupta, O. (2003): Cytoprotective and cytotoxic effects of curcumin: dual action on 
$\mathrm{H}_{2} \mathrm{O}_{2}$ induced oxidative cell damage in NG108-15 cells. Biol. Pharm. Bull., 26: 725728.

Meinecke, I.; Rutkauskaite, E.; Gay, S. and Pap, T. (2005): The role of synovial fibroblasts in mediating joint destruction in rheumatoid arthritis. Curr. Pharm. Des., 11: 563-568.

Moalic, S.; Liagre, B.; Le Bail, J. C. and Beneytout, J. L. (2001): Dose-dependent modulation of apoptosis and cyclooxygenase-2 expression in human 1547 osteosarcoma cell by NS-398. a selective cyclooxygenase- 2 inhibitor. International Journal of Oncology, 3: 533-540.

Mountz, J. D and Zhang, H. G. (2001): Regulation of apoptosis of synovial fibroblasts. Curr. Dir. Autoimmun., 3: 216-239.

Munford, R. S. and Pugin J. (2001): Normal responses to injury prevent systemic inflammation and can be immunosuppressive. Am. J. Respir. Crit. Care Med., 163: 316-321.

Naka, T.; Nishimoto, N. and Kishimoto, T. (2002): The paradigm of IL-6: from basic science to medicine. Arthritis Res., 4(3): S233-S242.

Nair, M. P.; Mahajan, S.; Reynolds, J. L.; Aalinkeel, R.; Nair, H.; Schwartz, S. A. and Kandaswami, $C$. (2006): The flavonoid quercetin inhibits proinflammatory cytokine (tumor necrosis factor alpha) gene expression in normal peripheral blood mononuclear cells via modulation of the NF-kappabeta system. Clin. Vaccine Immunol., 13: 319328 .

Newman, D. J. and Cragg, G. M. (2007): Natural products as sources of new drugs over the last 25 years. J. Nat. Prod., 70: 461-477.

Newman, D. J.; Cragg, G. M. and Snader, K. M. (2003): Natural products as sources of new drugs over the period 1981-2002. J. Nat. Prod., 66: 1022-1037.

Odontuya, G.; Hoult, J. R. S. and Houghton, P. J. (2005): Structure-activity relationship for anti-inflammatory effect of luteolin and its derived glycosides. Phytother. Res., 19: 782-786.

Patel, L.; Buckels, A.C.; Kinghorn, I. J.; Murdock, P. R.; Holbrook, J. D.; Plumpton, C.; Macphee, C. H. and Smith, S. A. (2003): Resistin is expressed in human macrophages and directly regulated by PPAR gamma activators, Biochem. Biophys. Res. Commun. 300: 472-476.

Park, C.; Moon, D. O.; Choi, I. W.; Choi, B. T.; Nam, T. J. and Rhu, C. H. (2007): Curcumin induces apoptosis and inhibits prostaglandin $\mathrm{E}(2)$ production in synovial fibroblasts of patients with rheumatoid arthritis. Int J Mol Med., 20 (3): 365-372.

Prasad, C. P.; Rath, G. and Mathur, S. (2009): Potent growth suppressive activity of curcumin in human breast cancer cells: Modulation of $\mathrm{Wnt} / \mathrm{beta}$-catenin signaling. Chem Biol Interact., 181: 263-271.

Qureshi, A. A.; Tan, X.; Reis, J. C.; Badr, M. Z.; Papasian, C. J.; Morrison, D. C. and Qureshi, N. (2011): Suppression of nitric oxide induction and pro-inflammatory cytokines by novel proteasome inhibitors in various experimental models. Lipids Health Dis., 10: 177-185.

Rahman, I.; Biswas, S. K. and Kirkham, P. A. (2006): Regulation of inflammation and redox signaling by dietary Polyphenols. biochemical pharmacology, 7 2: 1439-1452.

Rotelli, A. E.; Guardia, T.; Juárez, A. O.; Rocha, N. E. and Pelzer, L. E. (2003): Comparative Study of Flavonoids in Experimental Models of Inflammation. Pharmacological Research, 48: 601-606. 
Schaffer, M.; Bar-Sela, G. and Epelbaum, R. (2010): Curcumin as an anti-cancer agent: review of the gap between basic and clinical applications. Current Medicinal Chemistry, 7: 190-197.

Schumacher, H. R. and Chen, L. X. (2005): Injectable corticosteroids in treatment of arthritis of the knee. Am. J. Med., 118: 1208-1214.

Shakibaei, M.; John, T.; Schulze-Tanzil, G.; Lehmann, I. and Mobasheri, A. (2007): Suppression of NF- $\kappa \mathrm{B}$ activation by curcumin leads to inhibition of expression of cyclo-oxygenase-2 and matrix metalloproteinase-9 in human articular chondrocytes: implications for the treatment of osteoarthritis. Biochem. Pharmacol., 73: 1434-1445.

Siew, $C$. N. and Chan, F. K. (2010): NSAID-Induced Gastrointestinal and Cardiovascular Injury. Curr. Opin. Gastroenterol., 26 (6): 611-614.

Smith, W. L.; Dewitt, D. L. and Garavito, R. M. (2000): Cyclooxygenases: structural, cellular, and molecular biology. Annu. Rev. Biochem., 69: 145-182.

Tak, P. P. and Firestein, G. S. (2001): NF-kappaB: a key role in inflammatory diseases. J. Clin. Invest., 107: 7-11.

Towheed, T. E. (2006): Pennsaid therapy for osteoarthritis of the knee: a systematic review and metaanalysis of randomized controlled trials. J. Rheumatol., 33: 567-573.

Venkatesha, S. H. a, Berman, B. M. and Moudgil, K. D. (2011): Herbal medicinal products target defined biochemical and molecular mediators of inflammatory autoimmune arthritis. Bioorganic \& Medicinal Chemistry, 19: 21-29.

Vertuani, S.; Angusti, A. and Manfredini, S. (2004): The antioxidants and pro-antioxidants network: an overview. Curr. Pharm. Des., 10: 1677-1694.

Vingsbo, C. ; Sahlstrand, P. ; Brun, J. G. ; Jonsson, R. ; Saxne, T. and Holmdahl, R. (1996) : Pristane-induced arthritis in rats: a new model for rheumatoid arthritis with a chronic disease course influenced by both major histocompatibility complex and non-major histocompatibility comples genes. Am. J. Pathol., 149: 1675 - 1683.

Wang, Z.; Zhang, Y. and Banerjee, S. (2006): Notch-1 down-regulation by curcumin is associated with the inhibition of cell growth and the induction of apoptosis in pancreatic cancer cells. Cancer, 106: 2503-2513.

Yen, J.; Moore, B. E.; Nakajima, T.; Scholl, D.; Schaid, D. J.; Weyand, C. M. and Goronzy, J. J. (2001): Major histocompatibility complex class I-recognizing receptors are disease risk genes in rheumatoid arthritis. J. Exp. Med., 193: 1159-1167.

Yoon, J. H. and Baek, S. J. (2005): Molecular targets of dietary polyphenols with antiinflammatory properties. Yonsei Medical Journal, 46: 585-596.

Zhou, H.; Beevers, C. S. and Huang, S. (2011): Targets of curcumin. Curr. Drug Targets, 12 (3): 332-347. 


\section{مسلخص البـحـث}

دورالسيتوكين كدلالات حيوية فى الجرذان المصابة بالتهاب المفاصل وكفاءة

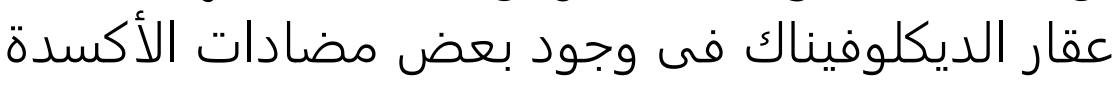

محمه إسلام أحمد حبيثي ـ فاطمة احمد النجىى". منى اسماعيل شاهين" . ماجدة سيد حسنين" . وفاء عبد اللطيف حماد"

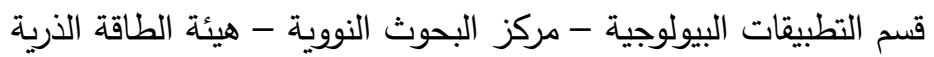

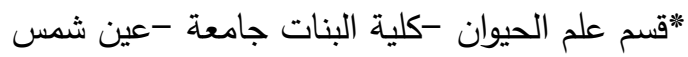

يعتبر مرض التهاب المفاصل من الأمراض المزمنة التي تتتشر في شعوب العالم وقد يورث عائليا إلى خمسة أجيال. ومن أعراض هذا المرض الشعور بالآلام وتورم المفاصل وقد تمتد إلى بعض الأنسجة من العظام والغضاريف ويسبب تآكلها أو تشوهها مما يؤدى الى اعاقة الحركة.

يعتبر الديكلوفيناك (غير استرويدى مضاد للالتهابات) علاج ناجح ذو كفاءة فى علاج الآلام الحادة والتهاب المفاصل. حيث أن ميكانيكية عمله غير معروفة بالضبط لكن يعتقد أن الميكانيكية الاساسية المسئولة عن دوره كمضاد للالتهاب ومثبط للالم هو أنه يمنع تخليق البروستاجلاندين عن طريق تثبيط نشاط انزيم الاكسجين الحلقى. أيضا له القدرة

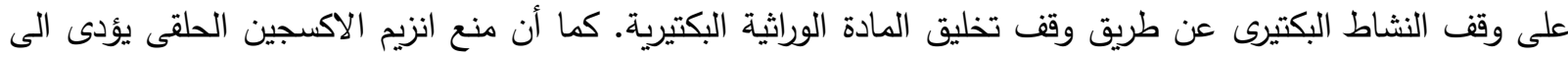

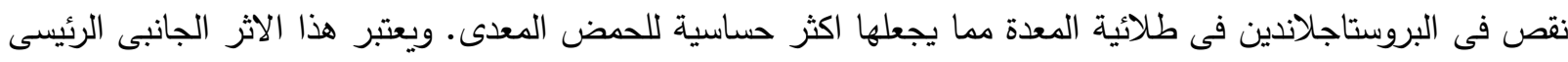
للايكلوفيناك.

أشارت الابحاث الى ان الكركم له قدرة عالية على معالجة الكثير من الامراض ومنها التهاب المفاصل. حيث يعمل على تقليل نشاط انزيم الاكسجين الحلقى-2 وانزيم الاكسجين الدهنى والانزيم المخلق لاكسيد النيتريك والذى يؤدى الى تقلى التليل الآلام والشعور بالراحة عند الحركة.

كما يعتبر الكوارسيتين مضاد قوى للاكسدة وذلك لقدرته على محاربة الشوارد الحرة وزيادة مناعة الجسم. وهذه الخصائص تسمح للكوارسيتين بأن يكون له القدرة على منع تكوين الدهون فائقة الأكسدة.

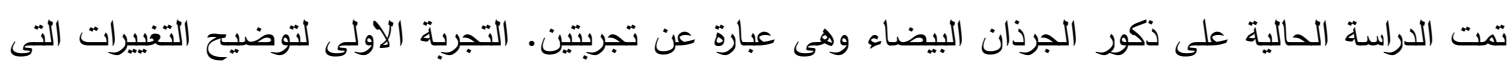

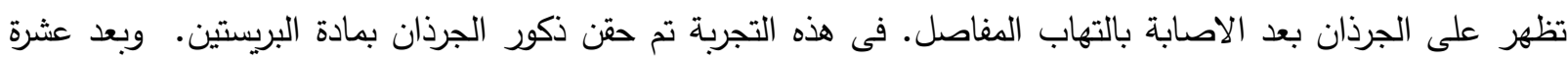

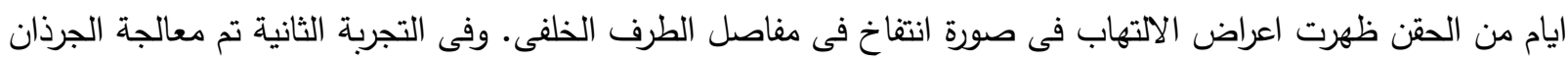
المصابة بالديكلوفيناك فقط وايضا بالديكلوفينالك مع الكركم أو/و الكوارسيتين ومعرفة تأثيرهما على القياسات المناعية والبيوكيميائية والنسيجية لبالية

وقد وجد ارتفاع معنوي لكل من البروتين المتفاعل-ج وانترلوكين المرقم-1 الفا وانترلوكين المرقم-6 ومعامل التتخر

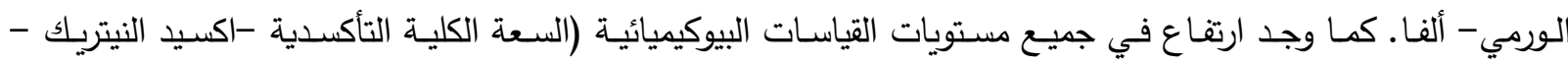

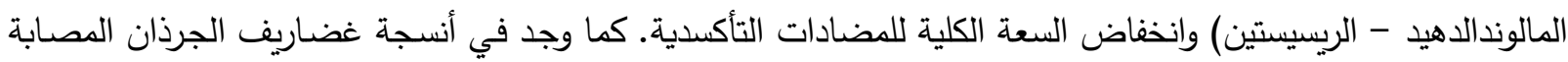

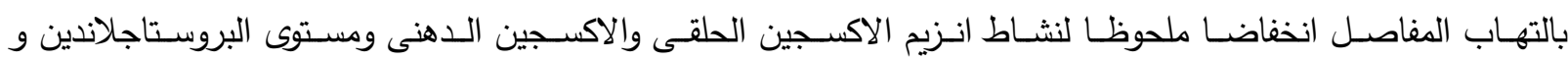
الريسيستين مقارنة بالمجموعة الضابطة. حدث تحسن في جميع القياسات السابق ذكرها للجرذان المصابة بالتهاب المفاصل بعد معالجتها بالكوركومين و /او الكوارسيتين وخليطهما معتمدا على مدة المعالجة (1-2-4 أسابيع). وقد نوقشت هذه النتائج في ضوء الأبحاث المتاحة. 